\title{
PEMANFAATAN PETA KONSEP (CONCEPT MAPPING) UNTUK MENINGKATKAN PEMAHAMAN SISWA TENTANG KONSEP SENYAWA HIDROKARBON
}

\author{
Luki Yunita, Ahmad Sofyan, Salamah Agung \\ Pendidikan Kimia UIN Syarif Hidayatullah Jakarta, luki.yunita@uinjkt.ac.id
}

\begin{abstract}
This research aims to improving students' comprehension of hydrocarbon. The research was participating by 28 students of tenth grade. The approach used in study was Classroom Action Research (CAR) with two cycles based on the planning, action, observation, and reflection. The first cycle was conducted in two sessions about hydrocarbon composition and its special characteristic. The last cycle performed in five sessions with the topic of group of hydrocarbon, reaction of hydrocarbon and the practical use of hydrocarbon. The test on fist cycle was to known the knowledge and understanding. In the second cycle, question based on application and analysis. The other instrument was student perception on learning by concept map, and interview questionnaire. The study suggested that learning using the concept map was significantly improve more than $10 \%$ of students' comprehension on the topic (from 70,3 to 80,3 ). There are not students whose score less than 60.0 on second cycle. There were found that students more contented when learning using the concept map, especially self-made. The result shows that more comprehension study on the use of concept maps in teaching chemistry.
\end{abstract}

Keywords: Classroom Action Research (CAR), hydrocarbon, concept mapping.

\begin{abstract}
Abstrak
Penelitian ini bertujuan untuk meningkatkan pemahaman siswa tentang senyawa hidrokarbon dengan pemanfaatan peta konsep. Penelitian ini dilaksanakan di SMA Muhammadiyah 8 Ciputat-Tangerang Selatan pada bulan April sampai dengan Juni 2007. Metode yang digunakan berupa Penelitian Tindakan Kelas (Classroom Action Research) dengan dua siklus. Siklus I dilakukan dua kali pertemuan dengan bahasan komposisi hidrokarbon dan kekhasan atom karbon. Siklus II dilakukan lima kali pertemuan pada bahasan penggolongan hidrokarbon, reaksi dan kegunaannya. Instrumen yang digunakan dalam penelitian ini adalah tes hasil belajar dengan siklus I soal dibatasi pada jenjang pengetahuan dan pemahaman, sedangkan siklus II mencapai jenjang aplikasi dan analisis. Instrumen lainnya berupa angket tanggapan siswa terhadap peta konsep, lembar observasi, serta wawancara guru dan siswa. Hasil penelitian menunjukkan ketercapaian indikator keberhasilan dengan peningkatan nilai rata-rata siswa siklus I sebesar 70,3 menjadi 80,8 pada siklus II. Pada siklus II tidak ada siswa yang mendapat nilai kurang dari 60,0. Angket tanggapan siswa terhadap peta konsep dalam pembelajaran terjadi peningkatan prosentase pada seluruh pernyataan dari siklus I ke siklus II. Penelitian ini membuktikan bahwa pemanfaatan peta konsep memberikan dampak positif bagi siswa dalam proses belajar mengajar dan hasil penelitian ini dapat dijadikan bahan masukkan bagi para pendidik dalam memilih strategi mengajar yang tepat untuk meningkatkan kualitas belajar mengajar yang diharapkan.
\end{abstract}

Kata Kunci: Penelitian Tindakan Kelas, hidrokarbon, peta konsep.

\section{PENDAHULUAN}

Pengembangan pendidikan memang sangat diperlukan sebagai upaya untuk meningkatkan kualitas sumber daya manusia. Hal ini dapat dilihat dari kualitas penanganan proses belajar mengajar, penanganan proses belajar yaitu bagaimana upaya mengaktifkan siswa dalam belajar. Perlunya suatu alternatif pengajaran yang diberikan kepada siswa untuk mencapai efektivitas dan efesiensi proses belajar mengajar. Guru sebagai tenaga pendidik diharapkan mampu menguasai strategi mengajar, salah satu faktor berhasilnya proses belajar mengajar adalah pada kecakapan guru menyusun pendekatan strategi belajar mengajar.
Strategi belajar mengacu pada perilaku dan proses-proses berpikir yang digunakan oleh siswa yang mempengaruhi apa yang dipelajari, termasuk proses memori. Pressley dalam Nur (2000), strategi-strategi belajar berperan operator-operator kognitif meliputi dan di atas proses-proses yang secara langsung terlibat dalam menyelesaikan tugas atau belajar. Strategi-strategi tersebut merupakan strategi-strategi yang digunakan siswa untuk memecahkan masalah belajar tertentu. Strategi belajar mengajar yang dikemukakan teori Ausebel tahun 1968 dalam Hajar (2000), yaitu belajar bermakna akan terjadi bila pengetahuan atau konsep-konsep baru dikaitkan dengan konsep- 
konsep yang sudah ada yang dimaksud dengan peta konsep. Dalam mata pelajaran Kimia yang syarat dengan konsep, dari konsep yang sederhana sampai konsep yang lebih kompleks dan abstrak, banyaknya konsep Kimia yang bersifat abstrak yang harus diserap siswa dalam waktu relatif terbatas menjadikan ilmu Kimia merupakan satu mata pelajaran yang tersulit bagi siswa saat ini. Sangatlah diperlukan pemahaman yang benar terhadap konsep dasar yang membangun konsep tersebut. Senyawa karbon merupakan bagian dari pokok bahasan Kimia di SMA yang relatif luas.

Pokok bahasan ini diajarkan di kelas X, XI dan XII. Pada kelas X senyawa karbon yang dibahas adalah pada bahasan senyawa Hidrokarbon. Selama ini, pembelajaran konsep senyawa karbon umumnya melalui pendekatan hafalan dengan metode ceramah dan bahkan siswa hanya diberi tugas merangkum materi tersebut. Dengan demikian materi yang cukup luas ini menjadi beban bagi siswa dan dampaknya adalah pada pokok bahasan senyawa karbon menjadi masalah yang menjemukan dan tidak menarik untuk dipelajari. Timbulnya masalah yang menjemukan, lelah, jenuh dan tidak menarik untuk dipelajari pada senyawa karbon, bila dalam proses belajar mengajar tidak menggunakan pendekatan strategi pembelajaran.

Kenyataannya, segala aktifitas belajar masih dominan dilakukan oleh guru dengan informasi hanya diterima dari guru tanpa melibatkan siswa membangun pemahamannya sendiri. Padahal tinggi rendahnya pemahaman siswa dapat terlihat dari proses belajar yang sedang berlangsung atau hasil belajarnya, karena pemahaman merupakan salah satu faktor penyebab keberhasilan dalam belajar. Hamzah (2000), mengungkapkan hubungan antara berbagai pengetahuan yang dimiliki dan menyesuaikannya merupakan bagian dalam memperoleh pemahaman. Siswa yang menghubungkan informasi dari satu sumber dengan sumber lainnya untuk mengaitkan antara informasi dengan pengetahuan yang telah dipelajari, maka siswa telah mendapatkan pembelajaran bermakna (Novak, et al., 2005). Oleh karena itu, pemahaman dapat dinyatakan baik apabila proses belajar menjadi menarik.

Menurut Pandley dalam Manihar (2000), peta konsep adalah merupakan media pendidikan yang dapat menunjukkan konsep ilmu yang dapat menunjukan konsep ilmu yang sistematis, yaitu dimulai dari inti permasalahan sampai pada bagian pendukung yang mempunyai hubungan satu dengan lainnya, sehingga dapat membentuk pengetahuan dan mempermudah pemahaman suatu topik pelajaran. Pendapat lain yang dijelaskan Kadir (2004), peta konsep adalah suatu gambar (visual), tersusun atas konsep-konsep yang saling berkaitan sebagai hasil dari pemetaan konsep. Pemetaan konsep merupakan suatu proses yang melibatkan identifikasi konsep-konsep dari suatu materi pelajaran dan pengaturan konsep-konsep tersebut dalam suatu hirarki, mulai dari yang paling umum, kurang umum dan konsep-konsep yang lebih spesifik. Pendapat senada disampaikan Barbara \& Sasa (2005), bahwa peta konsep adalah gambaran struktural dinyatakan dalam bentuk istilah dan label konsep yang dijalin dengan kata-kata penghubung sebagai proposisi.

Alberta (2005) menjelaskan, bahwa peta konsep dapat digunakan sebagai alat untuk memecahkan masalah di dalam pendidikan sebagai pilihan solusi atau sebagai alternatif. Pembiasaan dalam penggunaan peta konsep dalam pendidikan juga dapat menambah keuntungan pada proses pembelajaran. Sholahudin (2002), memanfaatkan peta konsep sebagai alat untuk mengetahui apa yang telah diketahui oleh siswa sekaligus menghasilkan proses belajar bermakna. Sehingga, keuntungan peta konsep dijadikan alat studi untuk mengevaluasi pelajaran atau rencana di dalam suatu pelajaran, atau keseluruhan kurikulum.

Peta konsep dalam proses belajar mengajar memperjelas pemahaman guru dan siswa dalam menfokuskan konsep-konsep dalam beberapa ide utama (Novak \& Gowin, 2006). Menurut Arif \& Abdullah (2003), Senyawa karbon selama ini diajarkan melalui penyampaian yang umumnya bersifat hafalan terhadap kumpulan fakta, kumpulan berbagai senyawa Kimia, kumpulan gugus fungsional dan kumpulan reaksi-reaksi Kimia yang seakan tidak terbatas. Materi Kimia yang cukup luas menjadi beban tersendiri bagi siswa. Konsep karbon yang cakupannya luas dapat difokuskan dengan peta konsep. Dikarenakan konsep senyawa karbon dalam kehidupan seharihari merupakan bagian yang tidak dipisahkan berdasarkan manfaat maupun bahayanya, maka pembelajaran dengan peta konsep dapat menghasilkan pemahaman yang utuh (meaning full learning) agar tidak mudah dilupakan.

Masalah-masalah yang terjadi dalam pembelajaran konsep karbon diakibatkan dari strategi pembelajaran yang hanya berorientasi pada target penyelesaian sejumlah materi dan bersifat hafalan konsep-konsep. Pembelajaran konsep karbon tersebut tidak dikaitkan dengan jalinan 
konse-konsep. Oleh karena itu, penelitian ini menggunakan strategi pembelajaran peta konsep dengan harapan dapat membantu proses terbentuknya pemahaman, apabila siswa terlibat langsung dalam segala aktifitas belajar. Sedangkan pemahaman yang dimaksud dalam penelitian ini adalah pemahaman siswa kelas X SMA Muhammadiyah 8 Ciputat-Tangerang Selatan dalam mempelajari konsep senyawa hidrokarbon. Sehingga penelitian ini bertujuan untuk mengkaji penerapan peta konsep dalam peningkatan penguasaan materi siswa khususnya pada konsep senyawa hidrokarbon, serta mengupayakan peningkatan pemahaman siswa terhadap konsep hidrokarbon setelah diterapkannya peta konsep.

\section{METODE PENELITIAN}

Penelitian ini merupakan Penelitian Tindakan Kelas (PTK). Penelitian tindakan kelas merupakan suatu kegiatan tindakan-tindakan langsung untuk memperbaiki atau meningkatkan efektivitas suatu program yang terdiri atas tiga langkah yaitu; (1) Perencanaan (planning), (2) Tindakan (action), dan Evaluasi (evaluation) hasil tindakan (Yasin, 2002). Ketiga langkah tersebut direfleksikan pada langkah terakhir secara kolaboratif dan parsipatif agar tindakan dapat diperbaiki untuk pencapaian hasil belajar siswa yang diharapkan (Rasyid \& Mansur, 2008).

Tindakan dalam penelitian ini dilakukan di satu kelas X SMA Muhammadiyah 8 Ciputat Tangerang Selatan pada semester Genap Tahun Pelajaran 2006/2007. Topik bahasan yang digunakan dalam pemberian tindakan adalah senyawa hidrokarbon. Tindakan ini untuk mengukur pemahaman siswa pada materi senyawa hidrokarbon dan tanggapan siswa dalam penggunaan peta konsep. Bentuk instrumen yang digunakan dalam pengumpulan data berupa tes pilihan ganda sebanyak 35 soal, lembar observasi, serta wawancara guru dan siswa.

Penelitian yang dilakukan melalui empat fase PTK. Fase pertama adalah Perencanaan Tindakan, fase ini guru merencanakan tindakan yang akan dilakukan dalam penelitian, baik berupa strategi pembelajaran sampai tugas-tugas yang akan diberikan pada siswa. Fase kedua Pelaksanaan Tindakan, dimana penelitian dilakukan sesuai dengan apa yang telah direncanakan. Perbedaan tindakan yang terjadi pada setiap siklus tergantung dari hasil refleksi pada siklus sebelumnya. Fase ketiga yaitu Observasi yang dilakukan sepanjang proses pembelajaran dalam penelitian ini dengan mencatat setiap kegiatan yang dilakukan oleh guru dan siswa. Sedangkan fase keempat adalah Refleksi. Fase ini dilakukan berdasarkan data-data yang didapat selama dan setelah tindakan untuk dianalisis kekurangan serta kelebihannya. Siklus dalam PTK ini terhenti bila batas indikator pencapaian telah didapatkan yaitu: 1) Rata-rata tes hasil belajar siswa mencapai nilai kriteria ketuntasan hasil belajar sebesar 75; 2) Tidak ada siswa yang mendapatkan nilai tes hasil belajar kurang dari 60; 3) Meningkatnya pemahaman siswa terhadap konsep senyawa hidrokarbon melalui tes hasil belajar dengan berdasarkan ketuntasan belajar $75 \%$.

\section{HASIL DAN PEMBAHASAN}

Hasil diskusi dengan guru kelas $\mathrm{X}$ diperoleh data kondisi awal proses belajar mengajar yang ada di kelas X pada pelajaran Kimia. Rendahnya pemahaman siswa pada pelajaran Kimia khususnya pada bahasan hidrokarbon kelas $\mathrm{X}$ pada tahun 2006. Serta hasil belajar Kimia yang diperoleh oleh siswa masih banyak yang belum mencapai ketuntasan belajar. Berdasarkan karakteristik ini dilakukanlah perencanaan untuk tindakan dalam penuntasan permasalahan.

\section{Tindakan Siklus I}

\section{a. Tahap Perencanaan}

Pada tahap ini peneliti direncanakan silabus dengan direncanakan tipe pembelajaran yang diterapkan dalam Rencana Pelaksanaan Pembelajaran (RPP). Penentuan pokok bahasan di tiap pertemuan yang disesuaikan dengan lembar latihan soal siswa. Pembuatan pedoman penilaian peta konsep dilakukan untuk mempermudah dalam pembuatan pedoman observasi dan angket wawancara. Agar mempermudah proses pembelajaran, di awal pembelajaran dialokasikan untuk menginformasikan peta konsep yang digunakan serta cara pembuatan dan memberikan pertanyaan berkaitan dengan pengetahuan awal mengenai Kimia karbon. Adapun bahasan pada siklus I adalah hidrokarbon dengan materi komposisi hidrokarbon dan kekhasan atom karbon.

\section{b. Tahap Pelaksanaan Tindakan dan Observasi}

Siklus I dilaksanakan dengan materi pokok bahasan komposisi dan kekhasan atom karbon. Pelaksanaan dipertemuan pertama dilakukan dengan guru membuka pelajaran tentang peta konsep yang selanjutnya dilakukan apersepsi dengan pertanyaan mengenai "apa yang kalian ketahui tentang hidrokarbon?". Kegiatan ini dimulai dengan pemberian materi hidrokarbon yang 
sesuai dengan kompetensi dasar kelas X. Materi ini mengenai Hidrokarbon paling sederhana walaupun hanya terdiri dua jenis unsur dari golongan senyawa karbon yang lain, hidrokarbon merupakan suatu kelompok besar senyawa. Kemudian siswa diberikan penjelasan oleh guru, sebelum masuk ke materi hidrokarbon pada pertemuan berikutnya untuk membahas terlebih dahulu mengenai penggolongan dan kekhasan senyawa karbon tersebut.

Pertemuan kedua, siswa dijelaskan oleh guru tentang materi mengidentifikasi unsur Karbon (C), Hidrogen $(\mathrm{H})$, dan Oksigen $(\mathrm{O})$ dalam senyawa karbon dengan menggunakan peta konsep. Siswa diberikan penjelasan yang terdapat dalam peta konsep dan diberikan contoh dalam kehidupan sehari-hari sehingga terjadi interaksi antara guru dengan siswa serta siswa dengan siswa. Siswa diberikan latihan soal oleh guru, siswa aktif mengerjakan dan turut berpartisipasi dalam menyelesaikan soal dan maju kedepan untuk mengerjakan dipapan tulis. Karena waktu masih tersisa siswa diberikan kesempatan oleh guru untuk bertanya mengenai materi yang belum jelas dan menyimpulkan materi yang telah diberikan.

Pertemuan ketiga, guru membuka pelajaran dan mengkondisikan kelas. Siswa diberikan penjelasan materi kekhasan atom karbon pada atom $\mathrm{C}$ primer, sekunder, tersier dan kuartener dengan menggunakan peta konsep. Hampir sebagian siswa memperhatikan dan ada seorang siswa yang bertanya pada materi yang belum jelas. Guru menerangkan dan memberikan penjelasan dari peta konsep. Ada dua orang siswa yang sibuk mengobrol di bangku belakang tidak memperhatikan penjelasan guru, sehingga secara tidak langsung mempengaruhi siswa lainnya untuk memberikan suasana yang gaduh. Guru mencoba mengkondisikan kelas pada akhirnya mereka kembali fokus memperhatikan pelajaran. Siswa diberikan latihan soal atau tugas tentang materi tersebut yang dikumpulkan. Setelah dikumpulkan guru menunjuk siswa untuk mengerjakan kembali di depan kelas ternyata siswa mengerjakan dengan benar soal yang diberikan guru berarti siswa telah memahami akan materi yang telah dipelajari. Pada akhir pelajaran siswa diberikan tugas untuk membuat peta konsep di rumah pada bahasan berikutnya penggolongan hidrokarbon sub bahasan alkana yang dikumpulkan pada pertemuan berikutnya dan siswa mempresentasikan hasil dari peta konsep yang telah dibuatnya.
Pertemuan keempat, evaluasi akhir siklus dengan memberikan tes hasil belajar pada bahasan komposisi dan kekhasan atom karbon. Selesai evaluasi siswa mengisi angket tentang tanggapan siswa terhadap peta konsep yang digunakan pada proses pembelajaran komposisi dan kekhasan atom karbon.

Pada kegiatan belajar mengajar siklus I dapat diuraikan bahwa: Pertama, terdapat sekitar 50\% dari siswa belum mengerti penggunaan peta konsep yang dijelaskan oleh guru dan siswa belum aktif untuk bertanya kepada guru serta siswa belum berani menjawab soal ketika diberikan pertanyaan mengenai hidrokarbon dan dominan siswa yang pintar selalu menjawab pertanyaan; Kedua, pembagian waktu antara penjelasan materi dengan peta konsep, pengerjaan tugas dan kesimpulan dari pembelajaran belum optimal.

\section{c. Tahap Evaluasi}

Pada pelaksanaan kegiatan belajar mengajar siklus I, masih terdapat kekurangan pada pertemuan awal. Lima hal kejadian yang terekam oleh peneliti dan observer. Pertama, sebagian besar siswa belum mengerti penggunaan peta konsep dan siswa kurang aktif bertanya kepada guru, walaupun hasil sudah menunjukkan peningkatan pemahaman sebesar $69,5 \%$ dengan rata-rata hasil belajar 70,3. Kedua, sebagian besar siswa tidak aktif dan belum berani menjawab soal ketika guru memberikan pertanyaan dan cenderung siswa yang pintar selalu menjawab pertanyaan, sehingga hanya 12 siswa dari 28 siswa yang mencapai ketuntasan belajar atau sekitar $42,8 \%$ berdasarkan frekuensi tes hasil belajar. Ketiga, siswa belum menunjukkan ketelitian dan ketekunan dalam mengikuti pembelajaran dengan aktivitas bercanda dan mengobrol tanpa mengerjakan tugas yang diberikan oleh guru. Temuan ini menggambarkan bahwa siswa belum mampu diberi kepercayaan untuk belajar mandiri. Keempat, siswa cenderung bertanya kepada guru mengenai soal yang sulit dipecahkan. Kelima, pembagian waktu antara penjelasan materi dengan peta konsep, pengerjaan tugas dan kesimpulan dari pembelajaran belum optimal.

\section{d. Tahap Refleksi}

Hasil analisis dan evaluasi data pada siklus I, baik secara kuantitatif maupun kualitatif diperoleh gambaran kurangnya penggunaan peta konsep, sehingga ada beberapa hal yang masih perlu diperbaiki, antara lain: 1) Bimbingan dan arahan guru perlu ditingkatkan dalam pemberian materi dengan peta konsep agar tidak terjadi kekeliruan 
dan kericuhan di dalam kelas; 2) Bimbingan guru perlu ditingkatkan khususnya dalam pengerjaan peta konsep, sehingga siswa dapat memahami peta konsep yang mereka buat dan memahami materi pelajaran; 3) Perlunya pengawasan intensif dari peneliti agar siswa lebih fokus dalam kegiatan belajar yang sedang berlangsung; 4) Perlu dibuat aturan yang tegas dalam aktifitas siswa yang tidak sesuai dengan proses pembelajaran, serta membuat aturan dalam bertanya dengan mengangkat tangan agar proses pembelajaran lebih tertib; 5) Diberikan motivasi kepada siswa untuk percaya diri dan jangan takut salah dengan jawaban soal yang mereka kerjakan untuk memberikan pendapatnya; 6) Siswa ditugaskan untuk membuat peta konsep di rumah agar siswa lebih kreatif dan aktif dalam memahami materi pelajaran.

\section{Tindakan Siklus II}

\section{a. Tahap Perencanaan}

Siklus II dilaksanakan dengan materi bahasan penggolongan hidrokarbon dan kegunaanya. Peneliti mencoba melakukan beberapa revisi tindakan untuk memperoleh hasil pembelajaran yang lebih baik lagi. Skenario pembelajaran diperbaiki dengan lebih mengaktifkan peran siswa. Penerapan belajar mandiri kepada siswa dilakukan dengan pemberian tugas peta konsep di rumah sebelum materi pelajaran dilaksanakan di sekolah. Tugas yang telah dilaksanakan dirumah selanjutnya dipresentasikan di dalam kelas.

\section{b. Pelaksanaan Tindakan dan Observasi}

Materi bahasan penggolongan hidrokarbon, reaksi dan kegunaannya terbagi menjadi lima pertemuan di siklus kedua. Pertemuan pertama, dimulai dengan pengulangan materi yang lalu dengan pertanyaan dan rangkuman tentang kekhasan atom karbon dan komposisi hidrokarbon. Pelajaran dilanjutkan dengan pengulasan materi alkana dengan presentasi hasil tugas peta konsep yang diinformasikan pada hari sebelumnya. Hasil presentasi dikoreksi guru bersama siswa lainnya secara langsung dengan meluruskan beberapa kekeliruan. Materi dilanjutkan guru dengan penjelasan berikutnya mengenai materi alkana dengan menggunakan peta konsep melalui metode tanya jawab apabila terdapat materi yang belum jelas. Pertemuan kedua sampai dengan kelima dilakukan pemunculan ingatan pembelajaran dari tiap pertemuan sebelumnya dengan metode tanya jawab. Pembahasan materi di siklus kedua ini dilakukan dengan pembahasan peta konsep hasil tugas rumah yang dilanjutkan dengan quis sebagai bagian dalam evaluasi. Catatan lapangan pada saat tindakan terlihat dengan tingginya aktifitas siswa yang menunjukkan adanya interaksi diskusi hasil pembuatan peta konsep. Diakhir siklus kedua (pertemuan keenam) dilakukan evaluasi dengan pemberian angket untuk mengetahui pendapat siswa tentang peta konsep yang mereka buat.

Pada pelaksanaan di siklus kedua didapatkan temuan berupa perubahan aktivitas siswa dan peningkatan hasil belajar. Adapun temuan pertama terlihat dari suasana kelas yang lebih teratur dalam pemfokusan pembelajaran melalui peta konsep. Kedua, optimalnya pembagian waktu antara penjelasan materi dengan peta konsep, pengerjaan tugas dan kesimpulan.

\section{c. Tahap Evaluasi}

Hasil observasi peneliti pada saat berlangsungnya kegiatan belajar mengajar siklus kedua diperoleh perbaikan dan perubahan yang lebih baik dari siklus I. Pertama, suasana pembelajaran di kelas lebih tertib dengan pemaksimalan pembelajaran melalui peta konsep. Kedua, antusias siswa yang tinggi dengan sikap berani memaparkan hasil tugasnya. Ketiga, keaktifan siswa dalam menjawab pertanyaan yang diajukan oleh guru dengan sebagian besar siswa merespon dengan mengangkatkan tangan sebelum menjawab. Ketiga, efisiennya waktu dengan peta konsep. Keempat, peningkatan nilai rata-rata tes dari 70,3 pada siklus I menjadi 80,8 pada siklus II. Keempat, tercapainya ketuntasan belajar siswa mencapai nilai 75 .

Hasil wawancara diperoleh pendapat siswa yang merespon positif peta konsep dalam pembelajaran. Respon tersebut dinyatakan bahwa peta konsep sangat bermanfaat dalam membantu pemahaman siswa terhadap materi Kimia. Pembelajaran yang sebelumnya menjenuhkan menjadi lebih menyenangkan dengan adanya peta konsep. Pemberian tugas dengan peta konsep sebelum pelajaran mempemudah siswa untuk mengikuti pelajaran di kelas.

Hasil wawancara guru mata pelajaran Kimia kelas X diperoleh kelebihan dari peta konsep. Peta konsep yang diterapkan di kelas dengan penugasan sebelumnya di rumah mempermudah guru dalam memanajemen waktu pembelajaran di kelas. Pembelajaran disertai peta konsep dianggap tepat digunakan pada konsep yang cenderung berupa teori khususnya pada senyawa hidrokarbon. Penerapan peta konsep mengaktifkan aktivitas dan 
kreativitas siswa. Antusias siswa dalam pembelajaran menjadi lebih tinggi dengan banyaknya jawaban siswa yang benar. Namun kekurangan dari peta konsep yaitu perlu adanya penjelasan yang maksimal dalam pembuatan dan penggunaan peta konsep, sehingga siswa tidak sulit dalam membaca peta konsep.

\section{d. Tahap Refleksi}

Berdasarkan hasil analisis dan evaluasi data pada siklus II baik secara kualitatif maupun kuantitatif diperoleh gambaran bahwa peta konsep telah efektif digunakan dalam proses belajar mengajar Kimia pada konsep hidrokarbon. Hal ini terlihat dari siklus I yang memperoleh nilai rata-rata siswa 70.3 menjadi 80.8 nilai rata-rata yang diperoleh pada siklus II. Pencapaian rata-rata kelas telah melebihi batasan indikator keberhasilan sebesar 75 .

\section{Tes hasil belajar siswa}

Hasil pelaksanaan Penelitian tindakan kelas yang dilakukan tersebut, didapatkan temuantemuan. Temuan pertama diungkapkan bahwa dengan penggunaan peta konsep dalam pembelajaran Kimia pada konsep senyawa hidrokarbon dapat meningkatkan pemahaman siswa. Hal tersebut ditunjukkan dalam rata-rata nilai tes hasil belajar yang diperoleh siswa meningkat dari siklus I sebesar 70,3 menjadi 80,8 pada siklus II. Bahkan tidak ada lagi siswa yang mendapat nilai kurang dari 60,0. Temuan kedua, terjadinya peningkatan ketuntasan belajar, dimana pada siklus I sebanyak 12 orang siswa $(42,8 \%)$ mencapai ketuntasan belajar. Setelah pelaksanaan pembelajaran di siklus II siswa yang mencapai ketuntasan belajar menjadi 18 orang siswa $(64,2 \%)$.

Hal yang menarik untuk dicermati adalah bergesernya hasil rata-rata nilai tes hasil belajar dikarenakan peta konsep yang dikerjakan di sekolah bersama-bersama berbeda dengan pemberian tugas peta konsep di rumah. Ternyata pemberian tugas peta konsep di rumah sebelum melaksanakan pembelajaran di sekolah, membuat siswa menjadi siap untuk belajar dan aktif dalam proses belajar Kimia di sekolah. Pembuatan peta konsep di rumah, siswa menjadi terlebih siap dengan membaca materi pelajaran yang akan dipelajari sehingga membantu mereka dalam memahami pelajaran Kimia saat proses belajarmengajar akan berlangsung. Dengan memahami pelajaran dapat membantu meningkatkan hasil belajar yang mereka peroleh. Siswa yang terlibat aktif pembuatan peta konsep memperoleh hasil pemahaman yang lebih baik. Hal ini berarti bahwa, strategi peta konsep merupakan strategi yang cukup efektif dalam pembelajaran sains atau Kimia.

a. Hasil Belajar Siswa Dilihat dari Jenjang Soal

Penggunaan peta konsep dapat mempengaruhi hasil belajar siswa dilihat dari jenjang soal. Peneliti menemukan terjadinya peningkatan pemahaman siswa. Persentase siswa dalam menjawab soal tes hasil belajar mengalami peningkatan dari siklus I sebesar $69,5 \%$ menjadi $76,5 \%$ di siklus II. Hal ini senada dengan penelitian yang dilakukan Widyastuti dalam Wahyudi (2002) yang menunjukkan, bahwa prestasi belajar siswa mengalami peningkatan yang diajar dengan menggunakan peta konsep dari pada siswa yang diajar tanpa menggunakan peta konsep.

Pemberian tes hasil belajar jenjang soal pada siklus I dan siklus II berbeda. Pada siklus I hanya terbatas pada jenjang soal pengetahuan dan pemahaman disesuaikan dengan materi bahasan yang dipelajari untuk mengetahui seberapa besar siswa dapat memahami materi ini. Sedangkan pada siklus II pemberian jenjang soal hanya pada tingkat penerapan (C4) sebagai tolok ukur atau variabel kriteria dalam peningkatan pemahaman siswa. Walaupun tingkatan SMA biasanya tolok ukur hasil belajar sampai pada tingkat evaluasi (C6), namun peneliti menyesuaikan sampai ke $\mathrm{C} 4$ berdasarkan materi yang diajarkan pada siklus II.

\section{b. Hasil kuesioner siswa}

Kuesioner yang telah diberikan kepada siswa, pada kedua siklus digunakan untuk membandingkan pernyataan yang setuju dengan adanya pemanfaatan peta konsep dalam pembelajaran. Hasil kuesioner ditemukan bahwa semua siswa menjawab setuju (100\%) dengan diterapkan peta konsep dalam pembelajaran Kimia, dikarenakan terasa adanya manfaat. Adapun sikap siswa dalam tanggapan dan kritik setelah kegiatan pembelajaran dapat dilihat pada Gambar 1 dan 2.

Siswa pada umumnya menanggapi bahwa peta konsep dapat digunakan dalam proses pembelajaran di siklus I (Gambar 1). Hal ini terlihat pada tingginya persentase di pernyataan keempat dan kelima yang menunjukkan hampir semua siswa setuju dengan adanaya peta konsep yang memuat konsep utama dalam pembelajaran, sehingga seluruh siswa merasakan manfaat penerapan peta konsep tersebut. Namun pada siklus I ini hanya sebagian siswa yang merasa siap dengan pemberian tugas rumah dalam bentuk peta konsep, karena lebih dari $60 \%$ siswa masih membutuhkan bantuan 
guru dalam pembuatan peta konsep (pernyataan kedua). Hal ini sesuai dengan Rusmansyah (2003) yang menyatakan, bahwa pemberian perlakuan dalam penelitian tindakan kelas diperlukan perbaikan yang menuntun siswa lebih menyukai pembelajaran tersebut.

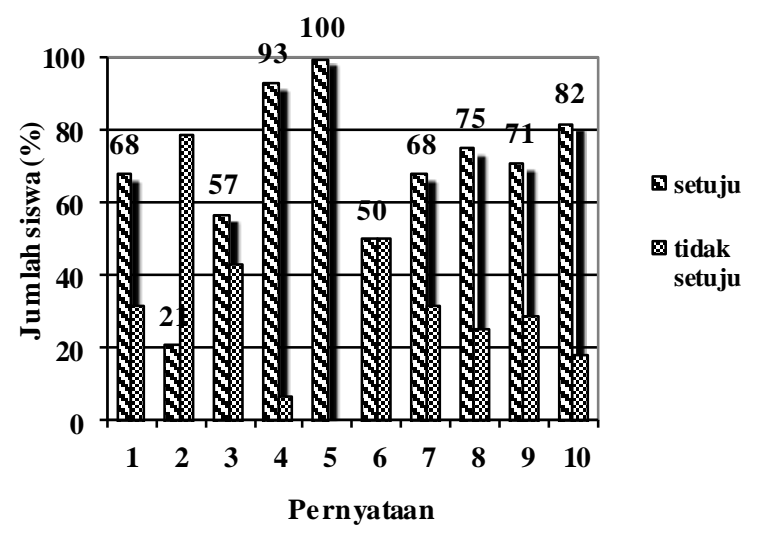

Gambar 1. Tanggapan Siswa terhadap Penerapan Peta Konsep Siklus

Gambar 2 hasil kuesioner yang dibagikan kepada siswa pada siklus II terhadap kegiatan pembelajaran menggunakan peta konsep menunjukkan bahwa siswa pada umumnya menanggapi pernyataan siklus II sangat baik. Hal ini terlihat pada tingginya persentase di pernyataan ketujuh yang menunjukkan semua siswa setuju dengan adanya peta konsep yang bermanfaat dalam pembelajaran Kimia, seluruh siswa merasakan manfaat penerapan peta konsep tersebut. Siklus II diperoleh 68\% siswa telah memahami maksud penggunaan peta konsep dan cara penggunaanya, serta hampir semua siswa tersebut memahami materi yang telah diajarkan.

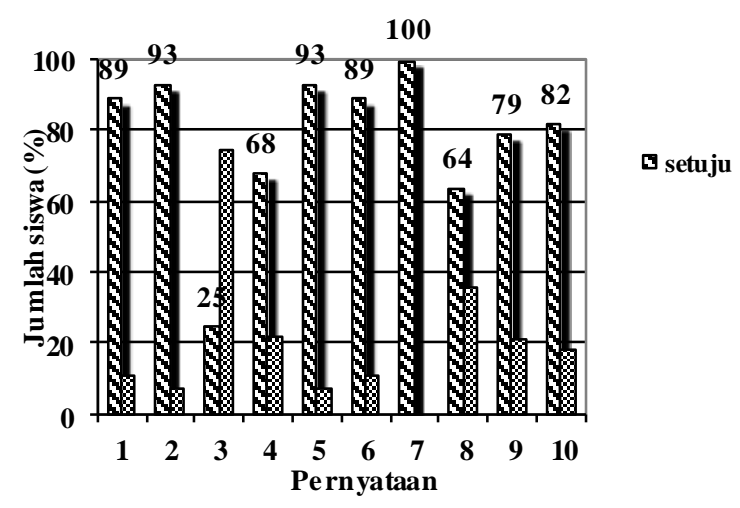

Gambar 2.Tanggapan Siswa terhadap Penerapan Peta Konsep II

Secara keseluruhan menunjukkan dari hasil kuesioner yang diperoleh juga mengungkapkan penggunaan peta konsep membantu siswa dapat memahami pelajaran Kimia pada materi yang telah guru ajarkan dengan peta konsep, peta konsep hanya memuat konsep yang penting pada suatu materi pelajaran, siswa menyatakan setuju sebelum membuat peta konsep mereka harus belajar terlebih dahulu sehingga mampu memahami materi yang akan dipelajari, dengan pemberian tugas peta konsep oleh guru membantu mereka menjadi siap untuk belajar Kimia di sekolah karena sebelum membuat peta konsep mereka belajar terlebih dahulu, dengan diberikan tugas peta konsep dan penerapan peta konsep dalam pembelajaran di sekolah karena dapat mempermudah dalam memahami pelajaran Kimia yang telah dipelajari.

Berdasarkan hasil wawancara siswa, dinyatakan bahwa penggunaan peta konsep dalam proses belajar-mengajar lebih mudah dipahami, bahkan membantu siswa dalam mempemudah mengikuti proses pembelajaran, serta mempermudah proses penyerapan materi pelajaran di kelas. Peta konsep ini didasarkan pada Ausabel dalam Plotnic (2006), yaitu tentang pelajaran penuh makna yang menekankan bahwa belajar pengetahuan baru adalah bergantung pada apa yang dikenal dengan kata lain pengetahuan baru memperoleh makna atau arti manakala dapat dihubungkan dengan suatu kerangka tentang pengetahuan yang telah ada. Hal ini berarti, peta konsep sangat efektif digunakan dalam proses pembelajaran Kimia untuk memberikan hasil yang signifikan terhadap hasil belajar yang diperoleh siswa.

\section{PENUTUP}

\section{Simpulan}

Pembelajaran dengan menggunakan peta konsep pada konsep senyawa hidrokarbon dapat meningkatkan pemahaman siswa. Hal ini terlihat dari: 1) Interaksi proses pembelajaran di kelas meningkat dari siklus I ke siklus II khususnya pada keaktifan siswa dalam proses belajar mengajar. Pemberian tugas peta konsep sebelum proses pembelajaran berlangsung dapat menumbuhkan kreativitas siswa dan kesiapan siswa untuk belajar di kelas. Siswa merasa tidak jenuh dalam belajar serta mudah memahami materi pelajaran yang telah diberikan; 2) Tercapainya batasan indikator keberhasilan tes hasil belajar untuk meningkatkan pemahaman siswa pada siklus II. Hal tersebut dapat dilihat dari jenjang soal yang diberikan dengan adanya peningkatan persentase hasil belajar Kimia siswa pada konsep senyawa hidrokarbon yang dikelompokkan berdasarkan jenjang soal; 3) Telah 
tercapainya batasan indikator keberhasilan tes hasil belajar pada siklus II dan terjadinya peningkatan nilai tes hasil belajar siklus I terhadap siklus II.

\section{Saran}

Berdasarkan hasil penelitian yang dilakukan telah memberikan banyak pengalaman dan manfaat bagi Penulis. Sebagai penutup, maka perkenankan Penulis untuk memberikan saran. Adapun saran yang diberikan sebagai berikut: (1) Guru bidang studi Kimia hendaknya terus mengembangkan peta konsep ini sebagai alat yang digunakan dalam kegiatan pembelajaran untuk lebih meningkatkan pemahaman siswa pada konsep-konsep Kimia lainnya; (2) Hendaknya guru lebih teliti dalam membimbing dan mengamati aktivitas siswa pada proses belajar-mengajar yang dilaksanakan di dalam kelas; (3) Peta konsep dapat digunakan sebagai alat yang praktis untuk mamahami pelajaran penuh makna dengan mengaitkan pengetahuan yang ada akan tetapi dapat menyimpan pengetahuan untuk waktu tertentu yang lama; (4) Perlu diadakan penelitian lebih lanjut dengan menggunakan peta konsep pada konsepkonsep Kimia lainnya; (5) Pihak sekolah hendaknya memperhatikan kelengkapan pembelajaran dalam upaya menunjang kegiatan proses belajar-mengajar yang lebih optimal.

\section{DAFTAR PUSTAKA}

Arif A. 2003. Peningkatan pemahaman siswa terhadap materi senyawa karbon bergugus fungsi melalui penyederhanaan materi Kimia”, dalam Jurnal Vidya Karya 22: 2.

Alberta C. 2005. A concept mapping toll to handle multiple formalisms. Knowledge science, Canada: Institute University of Calgary.

Dahar RW. 1996. Teori-teori Belajar, Jakarta: Erlangga.

Hajar A. 2000. Penggunaan Strategi Pemetaan Konsep dalam Proses Belajar Mengajar. Jakarta. Suara Guru.

Kadir. 2004. Efektivitas strategi peta konsep dalam pembelajaran sains dan matematika. Jurnal Pendidikan dan Kebudayaan 51:10.

Novak JD, Gowin DB. 2006. Learning How to Learn. Cambridge University Press. New York. P.93.
Mintzes JJ, James H Wanderse, Joseph D Novak. 1999. Assessing Science Understanding a Human contructivst view. Elsevier. London.

Nur M. 2000. Strategi-strategi Belajar. Surabaya: UNESA-University Press.h. 37

Rusmansyah. 2003. Meningkatkan pemahaman siswa terhadap konsep Kimia karbon. Jurnal Pendidikan dan Kebudayaan 042:9.

Plotnic, Eric. 2006. Concept Mapping: a Graphical System for Understanding the Relationship, dalam www.ericdigest.org.htm, diunggah pada 18 April 2007.

Situmorang M, Jamaludin P. 2000. Efektivitas Media Peta Konsep dalam Pengajaran Kimia Konsep Mol di Sekolah Menengah Umum. Jakarta: Pelangi Pendidikan.

Sasa A, Barbara S. 2005. Using Concept Maps in Teaching Organic Chemical Reaction. Pedagogical Paper, Slovenia.

Sholahudin A. 2002. Implementasi teori ausabel pada pembelajaran senyawa karbon. Jurnal Pendidikan dan Kebudayaan Jakarta. 039:8. h.810.

Tim Pelatih Proyek PGSM. 1999. Penelitian Tindakan Kelas (Classroom Action Research). Departemen Pendidikan dan Kebudayaan Direktorat Jenderal Pendidikan Tinggi Proyek Pengembangan Guru Sekolah Menengah. Secondary School Teacher Development Project.

Wahyudi. 2002. "Tingkatan Pemahaman Siswa Terhadap Materi Pembelajaran IPA", dalam Jurnal Pendidikan dan Kebudayaan 36: 8.

Yasin B. 2002. Penelitian Tindakan Kelas (Pendekatan Efektif-Perbaikan Mutu Pembelajaran dan Prestasi Siswa). Dinas Pendidikan Provinsi Nangroe Aceh Darussalam. Pengelolaan Pelatihan Guru SD, SLTP dan SLTA, Edisi Pertama. Malang: Penerbit Universitas Negeri Malang. 